\title{
Pola Pendidikan Informal dalam Organisasi Mahasiswa Ekstra Universiter
}

\author{
Bangun Setiyawan Nugroho \\ Pendidikan Luar Sekolah-Universitas Negeri Malang \\ Jl. Semarang 5 Malang. Email: b4n9un.pls@gmail.com
}

\begin{abstract}
This study aims to determine the underlying causes of informal education in the Student Organizations Extra university (OMEU) successfully reproduces many Indonesian leaders and what patterns of informal education in the association OMEU. The research approach used is qualitative case study research tradition, in this case the researchers used a multi-case. Sources of data in this study primarily obtained from informants who are leaders HMI, GMNI, and PMII in Malang. Data collection techniques used were interviewed, observation and documentation. The analysis technique used is the data management; reading and making notes; describe, classify, and interpretation; and present and visualize. The results of this study that (1) informal education in OMEU produce many leaders of Indonesia, (2) pattern of informal education in OMEU an interaction that occurs continuously between individuals, communities, and the environment.
\end{abstract}

Key Words: patterns of informal education, extra student organizations university

\begin{abstract}
Abstrak: Penelitian ini bertujuan untuk mengetahui sebab-sebab yang mendasari pendidikan informal dalam Organisasi Mahasiswa Ekstra Universiter (OMEU) berhasil mereproduksi banyak pemimpin bangsa Indonesia dan seperti apa pola pendidikan informal dalam pergaulan OMEU. Pendekatan penelitian yang digunakan adalah kualitatif dengan tradisi penelitian studi kasus, peneliti menggunakan multi kasus. Sumber data dalam penelitian ini diperoleh dari para informan yang merupakan tokoh HMI, GMNI, dan PMII di Kota Malang. Teknik pengumpulan data yang digunakan adalah wawancara, observasi dan dokumentasi. Teknik analisis yang digunakan adalah pengelolaan data; membaca dan membuat catatan; mendiskripsikan, mengklasifikasi, dan menginterpretasi; serta menyajikan dan memvisualisasikan. Hasil penelitian ini bahwa (1) pendidikan informal di OMEU menghasilkan banyak pemimpin bangsa Indonesia, (2) Pola pendidikan informal di OMEU merupakan interaksi yang terjadi secara terus menerus antara individu-individu, komunitas, dan lingkungan.
\end{abstract}

Kata kunci: pola pendidikan informal, organisasi mahasiswa ekstra universiter

Pendidikan informal adalah proses yang berlangsung sepanjang usia sehingga setiap orang memperoleh nilai, sikap, keterampilan, dan pengetahuan yang bersumber dari pengalaman hidup sehari-hari, pengaruh lingkungan termasuk didalamnya adalah pengaruh kehidupan keluarga, hubungan dengan tetangga, lingkungan pekerjaan dan permainan, pasar, perpustakaan, dan media massa. (Coombs, Prosser \& Ahmed; 1973:10).

Sedangkan menurut Axinn (1974:8) suatu aktivitas termasuk ke dalam pendidikan informal apabila kesengajaan belajar atau membelajarkan hanya timbul dari salah satu pihak antara pendidik atau peserta didik. Penjelasannya sebagai berikut, 1) suatu aktivi- tas disebut pendidikan informal apabila kesengajaan hanya timbul dari pihak pendidik untuk membantu peserta didik guna memperoleh pengalaman belajar, sedangkan pihak peserta didik tidak sengaja untuk belajar sesuatu dengan bantuan pendidik. 2) Demikian pula apabila hanya peserta didik yang sengaja untuk belajar sesuatu dengan bimbingan seorang pendidik sedangkan pihak pendidik tidak sengaja untuk membantu peserta didik tersebut, maka kegiatan ini tergolong pula ke dalam pendidikan informal (selfdirecting learning)

Pendapat Jeffs dan Smith (2005:11), yaitu pendidik informal membuat kegiatan yang dimaksudkan untuk merangsang pemikiran, untuk mendorong pem- 
Tabel 1. Daftar PTN \& PTS di Kota Malang yang Presiden BEM-nya Kader Organisasi Siswa Ekstra Kampus

\begin{tabular}{cll}
\hline No & \multicolumn{1}{c}{ PTN } & \multicolumn{1}{c}{ PTS } \\
\hline $\mathbf{1}$ & Universitas Negeri Malang (UM) & Universitas Merdeka (UNMER) Malang \\
$\mathbf{2}$ & Universitas Brawijaya (UB) & Universitas Islam Malang (UNISMA) \\
$\mathbf{3}$ & Universitas Islam Negeri (UIN) Malang & Universitas Muhammadiyah Malang (UMM) \\
$\mathbf{4}$ & - & Universitas Kanjuruhan (UNIKAN) Malang \\
$\mathbf{5}$ & - & Universitas Tribuana Tunggadewi (UNITRI) \\
\hline
\end{tabular}

belajaran. Pendidik informal berangkat untuk membantu orang lain untuk belajar, atau belajar sesuatu untuk diri kita sendiri (suatu proses pendidikan diri/ self-education). Keduanya dapat terjadi pada waktu yang sama. Kita belajar seperti yang kita ajarkan. Dalam percakapan kita belajar tentang orang-orang dan masyarakat dan juga belajar tentang seni dari pendidikan informal.

Menurut peneliti pendapat Coombs, Prosser \& Ahmed merupakan konsep dasar dari pendidikan informal, sehingga pendapat Axinn dan Jeffs \& Smith terkait pendidik informal dalam interaksi pendidikan informal perlu diluruskan. Keberadaan pendidik informal dalam interaksi pendidikan informal memang ada, akan tetapi tidak harus selalu ada. Sehingga dapat disimpulkan bahwa pendidikan informal merupakan proses sepanjang hayat di mana seseorang memperoleh dan menghimpun pengetahuan, keterampilan, sikap dan pandangan dari pengalaman dan terpaan lingkungan. Pengalaman diperoleh terutama melalui proses pendidikan diri (self-education), akan tetapi memungkinkan juga pengalaman tersebut diperoleh setelah melakukan interaksi dengan individu lain sebagai pendidik informal.

Menurut Jeffs, Rogers, \& Smith (2010:ix) pelopor pendidikan informal, dalam pendidikan orang dewasa dan pemuda, menempatkan penekanan khusus pada pembudayaan kehidupan kelompok. Secara khusus, mereka mendorong partisipasi dan self-government. Salah satu cara untuk memahami adalah gagasan "organisasi". Dalam penelitian ini organisasi yang dimaksud adalah organisasi mahasiswa ekstra universiter.

Organisasi mahasiswa ekstra universiter adalah organisasi mahasiswa yang tidak secara langsung dalam naungan perguruan tinggi sehingga pada umumnya tidak mendapat pendanaan kegiatan kemahasiswaan dari perguruan tinggi. Organisasi mahasiswa ekstra universiter memiliki hierarki kepengurusan mulai tingkat perguruan tinggi, tingkat kabupaten/ kota, tingkat provinsi, hingga tingkat nasional.

Para aktivis organisasi mahasiswa intra universiter pada umumnya berasal dari kader-kader organisa- si mahasiswa ekstra universiter ataupun aktivis-aktivis independen yang berasal dari berbagai kelompok studi atau kelompok kegiatan lainnya. Saat pemilihan umum untuk memilih pemimpin organisasi pemerintahan mahasiswa di suatu universitas, persaingan antar organisasi mahasiswa ekstra universiter sangat terasa. Tabel 1 yang menjelaskan bahwa Presiden Badan Eksekutif Mahasiswa (BEM) di berbagai Perguruan Tinggi Negeri (PTN) dan Perguruan Tinggi Swasta (PTS) di Kota Malang tahun 2012 merupakan kader dari organisasi mahasiswa ekstra universiter.

Dalam penelitian ini organisasi mahasiswa ekstra universiter yang dimaksud adalah Himpunan Mahasiswa Islam (HMI), Gerakan Mahasiswa Nasional Indonesia (GMNI), dan Pergerakan Mahasiswa Islam Indonesia (PMII). Alasan yang mendasari kenapa organisasi mahasiswa ekstra universiter tersebut yang dipilih adalah karena sentralnya peranan organisasi mahasiswa tersebut dalam sejarah gerakan mahasiswa Indonesia dan juga telah menghasilkan banyak pemimpin bangsa Indonesia yang terdiaspora ke berbagai sendi kehidupan diantaranya menjadi tokoh nasional, pimpinan perguruan tinggi, pimpinan partai politik, pemuka agama, pejabat negara, praktisi hukum, tokoh intelektual, pengusaha, dan tokoh organisasi kemasyarakatan.

Pemimpin-pemimpin bangsa Indonesia yang merupakan tokoh-tokoh organisasi mahasiswa ekstra universiter diantaranya seperti pada Tabel 2. Dari Tabel 2 terungkap data yang mencengangkan bahwa tokoh-tokoh organisasi mahasiswa ekstra universiter ternyata pernah dan atau sedang memimpin sembilan Lembaga Negara yang ada di Indonesia saat ini (UUD 1945 amandemen IV). Sedangkan untuk pimpinan perguruan tinggi khususnya di Kota Malang yang merupakan tokoh organisasi mahasiswa ekstra universiter diantaranya seperti pada Tabel 3.

Dari paparan di atas terungkap bahwa tokohtokoh organisasi mahasiswa ekstra universiter ternyata merupakan pemimpin-pemimpin bangsa yang berasal dari berbagai generasi. Hal ini membuktikan bahwa organisasi mahasiswa ekstra universiter tidak ha- 
Tabel 2. Tokoh Organisasi Mahasiswa Ekstra Universiter

\begin{tabular}{lll}
\hline $\begin{array}{l}\text { Megawati Soekarnoputri (Presiden } \\
\text { RI 2001-2004) }\end{array}$ & $\begin{array}{l}\text { Akbar Tanjung } \\
\text { (Ketua DPR RI 1999-2004) }\end{array}$ & $\begin{array}{l}\text { Abraham Samad } \\
\text { (Ketua KPK 2011-2015) }\end{array}$ \\
\hline $\begin{array}{l}\text { M. Jusuf Kalla (Wakil Presiden RI } \\
\text { 2004-2009) }\end{array}$ & $\begin{array}{l}\text { Irman Gusman } \\
\text { (Ketua DPD RI 2009-2014) }\end{array}$ & $\begin{array}{l}\text { Husni Kamil Malik } \\
\text { (Ketua KPU Pusat 2012-2017) }\end{array}$ \\
$\begin{array}{l}\text { Amien Rais } \\
\text { (Ketua MPR RI 1999-2004) }\end{array}$ & $\begin{array}{l}\text { Bagir Manan (Ketua MA 2001- } \\
\text { 2006, 2006-2008) }\end{array}$ & $\begin{array}{l}\text { Anwar Nasution } \\
\text { (Ketua BPK RI 2004-2009) }\end{array}$ \\
$\begin{array}{l}\text { Hidayat Nur Wahid } \\
\text { (Ketua MPR RI 2004-2009) }\end{array}$ & $\begin{array}{l}\text { Jimly Asshiddiqie } \\
\text { (Ketua MK 2003-2008) }\end{array}$ & $\begin{array}{l}\text { Mohammad Nuh } \\
\text { (MENDIKBUD 2009-2014) }\end{array}$ \\
$\begin{array}{l}\text { Taufiq Keimas } \\
\text { (Ketua MPR RI 2009-2014) }\end{array}$ & $\begin{array}{l}\text { Moh. Mahfud MD } \\
\text { (Ketua MK 2008-2013) }\end{array}$ & $\begin{array}{l}\text { Suryadharma Ali } \\
\text { (Menteri Agama 2009-2014) }\end{array}$ \\
$\begin{array}{l}\text { Mazuki Alie } \\
\text { (Ketua DPR RI 2009-2014) }\end{array}$ & $\begin{array}{l}\text { M.Busyro Muqoddas } \\
\text { (Ketua KY RI 2005-2011) }\end{array}$ & $\begin{array}{l}\text { Muhaimin Iskandar } \\
\text { (MENAKERTRANS 2009-2014) } \\
\text { Burhanuddin Abdullah (Gubernur BI }\end{array}$ \\
$\begin{array}{l}\text { Awang Faruq I. (Gubernur } \\
\text { KALTIM 2008-2013) }\end{array}$ & $\begin{array}{l}\text { Soekarwo (Gubernur Jawa Timur } \\
\text { 2009-2014) }\end{array}$ \\
$\begin{array}{l}\text { Hasyim Muzadi (Ketum PB NU } \\
\text { 1999-2004, 2004-2010) }\end{array}$ & $\begin{array}{l}\text { Salahuddin Wahid (Waka } \\
\text { Komnas HAM 2002-2007) }\end{array}$ & $\begin{array}{l}\text { Taufiq Ismail } \\
\text { (Sastrawan) }\end{array}$ \\
$\begin{array}{l}\text { Nurcholish Madjid (Cendikiawan } \\
\text { Muslim) }\end{array}$ & $\begin{array}{l}\text { Munir Said Thalib } \\
\text { (Aktivis HAM) }\end{array}$ & Eros Djarot (Budayawan) \\
\hline
\end{tabular}

Tabel 3. Pemimpin Perguruan Tinggi di Kota Malang yang Merupakan Tokoh Organisasi Mahasiswa Ekstra Universiter

\begin{tabular}{ll}
\hline Prof. Dr. Ir. Bambang Guritno (Rektor Univ. Brawijaya & $\begin{array}{l}\text { Prof. Dr. H. Suparno (Rektor Univ. Negeri } \\
\text { Malang 2006-2010, 2010-2014) }\end{array}$ \\
\hline Prof. Dr. Ir.Yogi Sugito (Rektor & $\begin{array}{l}\text { Dr. Muhadjir Effendi, M.AP } \\
\text { (Rektor UMM 2000- sekarang) }\end{array}$ \\
Univ. Brawijaya 2006-2010, 2010-2014) & - \\
Prof. Dr. Suko Wiyono (Rektor Univ. Wisnu Wardhana & \\
2006- sekarang) & \\
\hline
\end{tabular}

nya berhasil menghasilkan pemimpin bangsa, akan tetapi juga berhasil mereproduksi pemimpin bangsa.

Dari fenomena tersebut menunjukkan begitu dahsyatnya pendidikan informal yang terjadi dalam organisasi mahasiswa ekstra universiter sehingga peneliti tertarik mendalami mengapa pendidikan informal dalam organisasi mahasiswa ekstra universiter berhasil mereproduksi banyak pemimpin bangsa dan bagaimana pola pendidikan informal dalam organisasi mahasiswa ekstra universiter.

\section{METODE}

Dalam penelitian ini menggunakan pendekatan penelitian kualitatif dengan menggunakan tradisi studi kasus. Studi kasus dalam penelitian ini diartikan sebagai eksplorasi tentang sebuah sistem yang terbatas dari satu ataupun beberapa kasus melalui pengumpulan data yang rinci, mendalam dan mencakup multi sumber informasi yang kaya dengan konteks (Moe- dzakir, 2010:169). Sistem terbatas ini dibatasi oleh waktu dan tempat. Substansi dalam penelitian ini adalah pendidikan informal dan konteks dalam penelitian adalah organisasi mahasiswa ekstra universiter di Kota Malang.

Dalam penelitian ini menggunakan multi kasus, format yang digunakan adalah pertama memberikan gambaran yang rinci setiap kasusnya dan tema-tema yang terdapat di dalam kasus yang bersangkutan (analisis dalam kasus), diikuti oleh analisis tematik diantara beberapa kasus tersebut (analisis lintas kasus), kemudian penonjolan atau interpretasi makna kasus. Pada tahap interpretatif final, peneliti melaporkan pelajaran-pelajaran yang dapat dipetik dari kasus yang bersangkutan (Cresswell, 1998).

Dalam penelitian multi kasus menurut Yin (2003), setiap kasus harus dipilih secara hati-hati agar kasusnya: (a) memprediksi hasil yang serupa (replika literal) atau (b) membuahkan hasil yang berlatar belakang berbeda tetapi untuk alasan-alasan tertentu 
seperti yang diprediksi (replika teoritis). Berikut merupakan proses penelitian studi multi kasus yang digunakan dalam penelitian (Gambar 1).

Dari gambar dapat dijelaskan bahwa penelitian bermaksud untuk mengembangkan teori pendidikan informal, kemudian konteks penelitiannya adalah organisasi mahasiswa ekstra universiter dan desain pengumpulan datanya menggunakan studi multi kasus. Setelah itu peneliti melakukan persiapan penelitian, pengumpulan data, dan analisis konteks penelitian meliputi: (1) Himpunan Mahasiswa Islam (HMI), (2) Gerakan Mahasiswa Nasional Indonesia (GMNI), dan (3) Pergerakan Mahasiswa Islam Indonesia (PMII) di Kota Malang. Langkah berikutnya peneliti membuat laporan kasus tunggal, yaitu laporan kasus HMI, GMNI, dan PMII. Setelah membuat laporan kasus tunggal peneliti menganalisis dan mengambil simpulan lintas kasus. Setelah mengambil simpulan lintas kasus peneliti melakukan modifikasi teori dan mengembangkan implikasi kebijakan. Tahap akhir penelitian adalah membuat laporan lintas kasus pola pendidikan informal dalam organisasi mahasiswa ekstra universiter.

\section{Kehadiran Peneliti}

Penelitian kualitatif berusaha mengungkapkan gejala secara menyeluruh dan sesuai dengan konteks (holistic-kontekstual) melalui pengumpulan data dari latar alami dengan memanfaatkan diri peneliti sebagai instrumen kunci. (Universitas Negeri Malang, 2010: 28)

Peneliti yang betul-betul terlatih dan berpengalaman diperlukan dalam penanganan studi kasus yang berkualitas tinggi dikarenakan adanya interaksi yang terus-menerus antara isu-isu teoritis yang akan diteliti dan data yang akan dikumpulkan. Selama pengumpulan data, hanya peneliti yang lebih berpengalaman yang akan mampu memanfaatkan peluang-peluang tak terduga, selalu selamat dari kemungkinan terperangkap dan bersikap cukup hati-hati dalam menghadapi prosedur yang bias (Yin, 2003).

Dalam penelitian ini peneliti sebagai instrumen kunci terus terlibat dalam proses pengumpulan data secara menyeluruh dan mendalam pada HMI, GMNI, dan PMII sehingga peneliti dapat benar-benar memahami tiap-tiap kasus dan bahkan lintas kasus penelitian. Peneliti secara terus menerus melakukan kajian yang medalam antara isu-isu teoritis yang diteliti dan data yang telah dikumpulkan, sehingga peneliti bersikap hati-hati dalam pengumpulan data dan terus berusaha memanfaatkan peluang-peluang yang tak terduga.

\section{Lokasi Penelitian}

Penentuan lokasi penelitian di Kota Malang didasari oleh beberapa alasan, yaitu Kota Malang merupakan salah satu pusat kaderisasi organisasi mahasiswa ekstra universiter di Indonesia, khususnya Him-

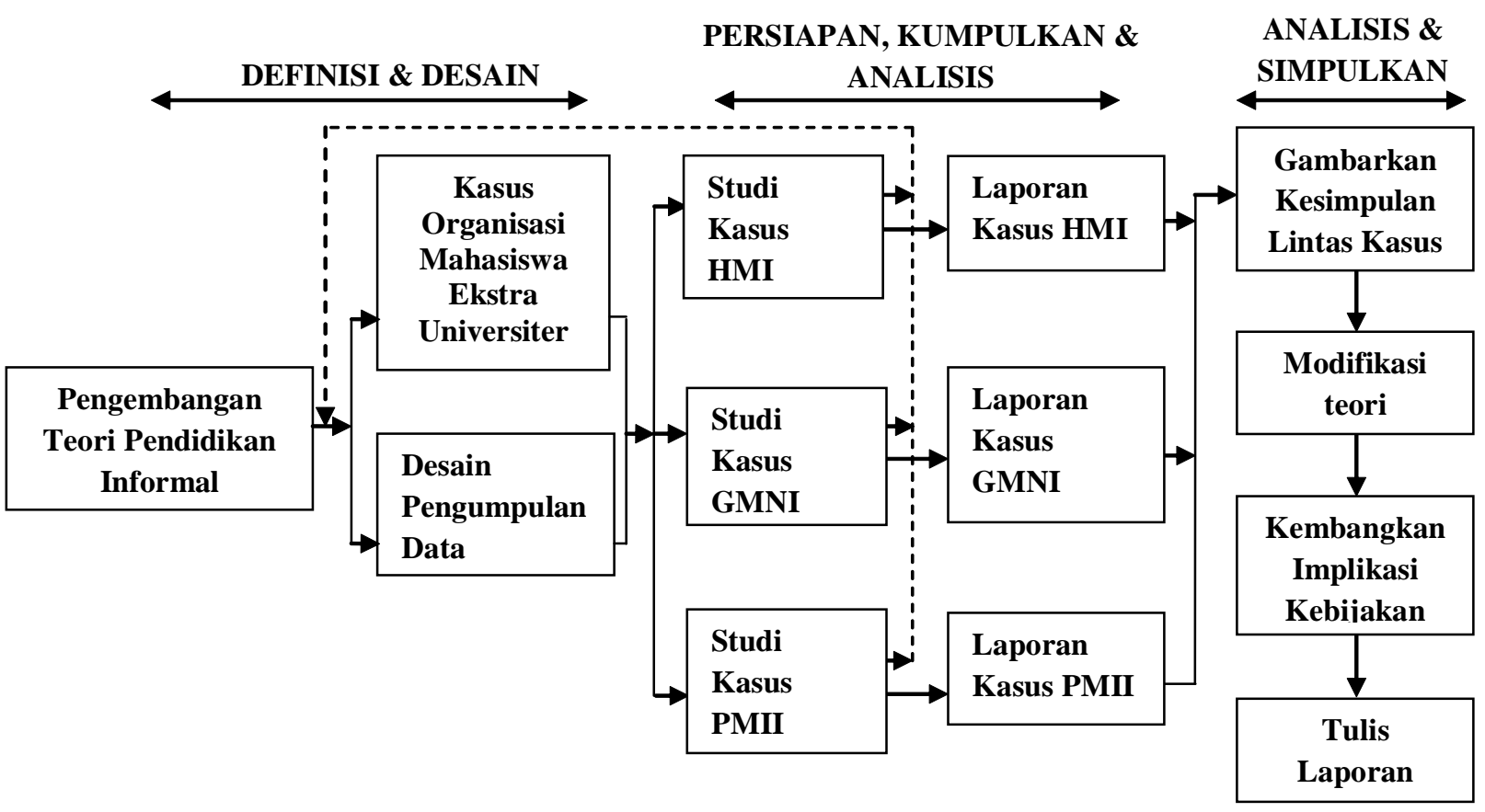

Gambar 1. Metode Studi Kasus (Yin, 2003: 50) 
punan Mahasiswa Islam (HMI), Gerakan Mahasiswa Nasionalis Indonesia (GMNI), dan Pergerakan Mahasiswa Islam Indonesia. Kader-kader HMI, GMNI, PMII di Kota Malang pernah menduduki jajaran pimpinan pengurus pusat di Jakarta, disamping itu HMI, GMNI, dan PMII di Kota Malang telah berhasil mereproduksi banyak pemimpin bangsa Indonesia.

Pengumpulan data disesuaikan dengan permintaan dan aktivitas informan penelitian sehingga dalam penelitian ini pengumpulan data dilakukan di berbagai tempat. Pengumpulan data pada kasus HMI diantaranya dilakukan di sekretariat HMI Cabang Malang (Jl. Jenderal Basuki Rahmad No. 101), Kedai dan Gerai “Smooth" ( Jl. Sunan Kalijogo No. 3 Kav. 1), Kantor Malang Corruption Watch (MCW) (Jl. Joyosuko Metro No. 42), dan Kantor Playgroup Qur'ani TPI Nurul Huda (Jl. Mayjend Panjaitan Gg. 15).

Pengumpulan data pada kasus GMNI dilakukan di sekretariat DPC GMNI Malang (Jl. Sultan Agung No. 08), depan Ruang Registrasi Gedung A3 UM, rumah dr. Subagjo (Jl. Muria No. 6), rumah Cokro Wibowo (Pondok Harapan Indah D6B), Warung Kuning (Jl. Bendungan Sutami), dan Kantor DPC PNI Marhaenisme (Jl. Andalas).

Sedangkan pengumpulan data pada kasus PMII dilakukan di Sekretariat PMII Cabang Kota Malang (Jl. Mayjend Pandjaitan No. 164), rumah Andry Dewanto (Jl. Keramat No. 70B - Singosari), Warung Nasi Tempong (Jl. Laksda Adi Sucipto), Rumah Paman Hasanuddin Wahid (Jl. Bromo - Batu), dan rumah mertua Hasanuddin Wahid (Semanding-Dau).

\section{Sumber Data}

Sumber data dalam penelitian ini di dapat dari hasil wawancara, observasi dan dokumentasi. Dalam penelitian, informan penelitiannya merupakan tokoh organisasi mahasiswa ekstra universiter (HMI, GMNI, dan PMII) di Kota Malang. Penentuan informan berdasarkan beberapa kriteria. (1) Individu yang sedang atau pernah menjadi pengurus aktif di organisasi mahasiswa ekstra universiter di Kota Malang. (2) Individu yang kaya akan pengalaman mengenai pendidikan informal di organisasi mahasiswa ekstra universiter di Kota Malang. (3) Masih berinteraksi dengan organisasi mahasiswa ekstra universiter di Kota Malang.

Sesuai dengan kriteria yang ditentukan, informan dalam penelitian meliputi informan dari HMI, GMNI, dan PMII. Jumlah keseluruhan informan dalam penelitian adalah 9 orang yang terdiri dari informan tiaptiap organisasi sejumlah 3 orang. Informan di tiap organisasi sejumlah 3 orang merupakan 1 orang Ketua Cabang dan 2 orang alumni HMI, GMNI, dan PMII.

Informan HMI adalah Jarot Hartanto (Ketua Umum Cabang HMI Malang 2011-2013), Lutfhfi J. Kurniawan (Ketua Cabang HMI Malang 1993-1994, sekarang beraktifitas sebagai Ketua Dewan Pengurus Perkumpulan Malang Corruption Watch dan Direktur Intrans Publishing Group), Nugraha Adi Kusuma (Ketua Badan Koordinasi HMI Jawa Timur 1997-1999, pernah menjadi sekretaris DPD Partai Golkar Kabupaten Malang dan Wakil Ketua DPC Partai Demokrat 2008, kemudian sekarang lebih memilih beraktifitas sebagai Kepala Playgroup Qur'ani TPI Nurul Huda Kota Malang).

Informan GMNI adalah Eki Robbi Kusuma (Ketua DPC GMNI Malang 2013-2015), dr. Subagjo (Ketua Umum DPC GMNI Malang 1982, sekarang beraktivitas sebagai dokter bedah Rumah Sakit Saiful Anwar dan Ketua Ikatan Dokter Indonesia Malang Raya), Cokro Wibowo Sumarsono (Sekretaris Jenderal Presidium DPP GMNI 2008-2011, sekarang beraktivitas sebagai Dosen Universitas Bung Karno Jakarta dan sebagai petani).

Informan PMII adalah Dwi Fitri Wiyono (Ketua Umum Cabang PMII Kota Malang 2012-2013), Andry Dewanto Ahmad (Ketua Umum Cabang PMII Kota Malang 1994-1995, sekarang beraktivitas sebagai Ketua KPUD Jawa Timur dan Newsletter Simpul Demokrasi Averroes Community), M. Hasanuddin Wahid (Ketua PB PMII 2005-2007, sekarang beraktivitas sebagai Staf Ahli Fraksi Partai Kebangkitan Bangsa DPR RI).

\section{Prosedur Pengumpulan Data}

Pengumpulan data primer dilakukan dengan cara observasi non-partisipasi dan partisipasi, serta wawancara bebas dan wawancara terbimbing (Fatchan, 2011: 189-190). Sedangkan data sekunder diperoleh dengan cara studi dokumentasi pada masing-masing organisasi mahasiswa ekstra universiter di Kota Malang.

\section{Observasi}

Selama melakukan observasi, sekaligus dilakukan wawancara mendalam. Langkah pertama, peneliti menyiapkan lembar observasi dan wawancara, setelah itu akan langsung dianalisis tanpa menunggu hari berikutnya, karena dikhawatirkan sudah terjadi bias. Pada pengamatan tahap ini, peneliti diharapkan sudah menemukan pemahaman yang mendalam atau 
"makna" sehingga mampu menyusun "proposisi-proposisi atau teori substantif" (Spradley, 1979).

Dalam penelitian ini peneliti lebih banyak menggunakan teknik observasi partisipasi, sehingga peneliti memahami secara mendalam fokus penelitian dari masing-masing kasus pada HMI, GMNI, dan PMII. Peneliti juga dapat mendapatkan pemahaman secara utuh fokus penelitian lintas kasus pada organisasi mahasiswa ekstra universiter tersebut. Proses observasi kasus HMI diantaranya dilakukan di sekretariat HMI Cabang Malang pada hari kamis tanggal 18 April 2013 jam 10.20-14.35 WIB untuk mengamati pola interaksi pendidikan informal yang sehari-hari terjadi dan pada hari selasa tanggal 30 April 2013 jam 19.3521.10 WIB di Fajar Teaching Resto (Jl. Veteran) melakukan observasi aktivitas diskusi antar organisasi mahasiswa ekstra universiter yang diselenggarakan oleh HMI UM.

Observasi kasus GMNI diantaranya dilakukan pada saat terjadi aktivitas diskusi antara pengurus GMNI Brawijaya dengan alumni di Kantor DPC PNI Marhaenisme Kota Malang pada hari senin tanggal 8 April 2013 pukul 18.40-22.05 WIB, Observasi pola interaksi pendidikan informal yang sehari-hari terjadi di sekretariat DPC GMNI Malang pada hari rabu tanggal 17 April 2013 pukul 17.55-18.40 WIB, dan observasi interaksi pendidikan informal antar alumni GMNI pada hari rabu tanggal 19 Juni 2013 di rumah Cokro Wibowo pukul 16.40-19.25 WIB.

Observasi kasus PMII dilakukan pada hari rabu tanggal 27 Maret 2013 di sekretariat PMII Cabang Kota Malang untuk mengamati pola interaksi pendidikan informal yang sehari-hari terjadi dan pada hari rabu tanggal 17 April 2013 pukul 20.20-23.05 WIB di rumah M. Baidlowi (alumni PMII) untuk mengamati kegiatan istighosah rutin alumni dan pengurus PMII UM.

\section{Wawancara}

Wawancara terbimbing atau terstruktur ialah wawancara yang dilakukan terhadap informan dengan menggunakan pedoman wawancara yang akurat (yang telah direvisi sesuai dengan tujuan penelitian dan kondisi lapangan) berisi pertanyaan-pertanyaan bersifat hipotetik, interpretatif, argumentatif, dan bersifat mengarahkan (Miles dan Huberman, 1994). Pengumpulan data melalui wawancara berhenti apabila sudah terjadi pengulangan informasi pada data yang sama atau sudah tidak lagi diperoleh data yang baru.

Wawancara pada informan HMI diantaranya dilakukan dengan Jarot Hartanto (Ketua Umum Cabang HMI Malang 2011-2013) pada hari kamis tang- gal 18 April 2013 pukul 10.20-14.35 WIB di Sekretariat HMI Cabang Malang dan pada hari selasa tanggal 30 April 2013 pukul 21.40-00.35 WIB di Kedai dan Gerai "Smooth"; Wawancara dengan Luthfi J. Kurniawan (Alumni HMI) dilakukan di Kantor Malang Corruption Watch pada hari sabtu tanggal 27 april 2013 pukul 14.05-15.50 WIB dan pukul 19.10-20.40 WIB; Wawancara dengan Nugraha Adi Kusuma (Alumni HMI) pada hari minggu tanggal 19 Mei 2013 pukul 19.20-22.35 WIB di Kantor Playgroup Qur'ani TPI Nurul Huda.

Wawancara pada informan GMNI dilakukan dengan Eki Robbi Kusuma (Ketua DPC GMNI Malang 2013-2015) pada hari rabu tanggal 17 April 2013 pukul 11.20-12.25 WIB di depan Ruang Registrasi Gedung A3 UM dan pada hari senin tanggal 29 April 2013 pukul 20.35-21.50 WIB di Sekretariat DPC GMNI Malang; Wawancara dengan dr. Subagjo (Alumni GMNI) di rumah yang bersangkutan pada hari rabu tanggal 17 April 2013 pukul 19.05-20.10 WIB dan pada hari Kamis tanggal 18 April 2013 pukul 18.10-19.50 WIB; Wawancara dengan Cokro Wibowo Sumarsono (Alumni GMNI) pada hari jum' at tanggal 29 Maret 2013 pukul 16.20-20.55 WIB di rumah yang bersangkutan, pada hari senin tanggal 8 April 2013 pukul 12.45-15.40 WIB di Warung Kuning, dan pada hari senin tanggal 8 April 2013 pukul 18.40-22.05 WIB di Kantor DPC PNI Marhaenisme.

Wawancara dengan informan PMII dilakukan dengan Dwi Fitri Wiyono (Ketua Umum Cabang PMII Kota Malang 2012-2013) di Sekretariat PMII Cabang Kota Malang pada hari rabu 27 Maret 2013 pukul 18.10-21.35 WIB dan pada hari selasa tanggal 16 April 2013 pukul 16.25-17.45 WIB; Wawancara dengan Andry Dewanto Ahmad (Alumni PMII) pada hari minggu tanggal 17 Maret 2013 pukul 07.05-08.25 WIB di rumah yang bersangutan dan pada hari jum' at tanggal 19 April 2013 pukul 19.10-20.15 WIB melalui telepon; dan Wawancara dengan M. Hasanuddin Wahid pada hari sabtu tanggal 30 Maret 2013 pukul 16.50-17.35 WIB di Warung Nasi Tempong, pada hari senin tanggal 1 April 2013 pukul 00.05-02.40 WIB di rumah paman yang bersangkutan, pada hari Jum'at tanggal 19 April 2013 pukul 13.25-15.05 WIB, dan pada hari senin tanggal 29 April 2013 pukul 11.0512.20 WIB di rumah mertua yang bersangkutan.

\section{Dokumentasi}

Teknik dokumentasi dilakukan secara selektif terutama hal-hal yang berkaitan dengan penelitian. Dokumentasi merupakan bentuk pengumpulan data melaui pemetaan dan penggambaran secara umum 
bagian-bagian dari yang akan diteliti dalam bentuk dokumen. Teknik ini sangat penting dalam pengumpulan data, karena dokumentasi dapat melengkapi kekurangan data yang diperoleh melalui wawancara mendalam dan observasi langsung, selain sebagai bahan dalam triangulasi untuk checking antara sumber data yang satu dengan sumber data yang lainnya.

Dalam penelitian, teknik dokumentasi dilakukan bersamaan dengan proses observasi dan wawancara. Teknik ini dilakukan secara selektif dan melengkapi data yang telah terkumpul dari teknik observasi dan wawancara. Hasil teknik dokumentasi berupa fotofoto, file-file kegiatan, dan buku-buku yang berkaitan dengan pendidikan informal pada HMI, GMNI, dan PMII di Kota malang.

\section{Analisis Data}

Peneliti menggunakan analisis data spiral Creswell (1998:143) yang dapat dilihat pada Gambar 2. Berdasarkan Gambar 2 bahwa dalam menggunakan analisis data spiral, peneliti terlibat dalam suatu proses dinamis yang bergerak dari satu lingkaran ke lingkaran berikutnya dan bukan proses linear yang sudah baku. Proses dimaksud meliputi: (a) pengelolaan data yang menghasilkan unit atau fail; (b) membaca dan membuat catatan yang menghasilkan catatan-catatan berdasarkan lintas pertanyaan dan refleksi; (c) mendiskripsikan, mengklasifikasi, menginterpretasi yang menghasilkan konteks, kategori, dan komparasi; dan (d) menyajikan, memvisualisasikan yang menghasilkan matriks.

Dalam penelitian ini, setelah data terkumpul kemudian dikelola dan kelompokan berupa unit-unit. Kemudian data dibaca secara keseluruhan dan direfleksikan berupa catatan-catatan yang berdasarkan lintas pertanyaan. Setelah itu data didiskripsikan, di-

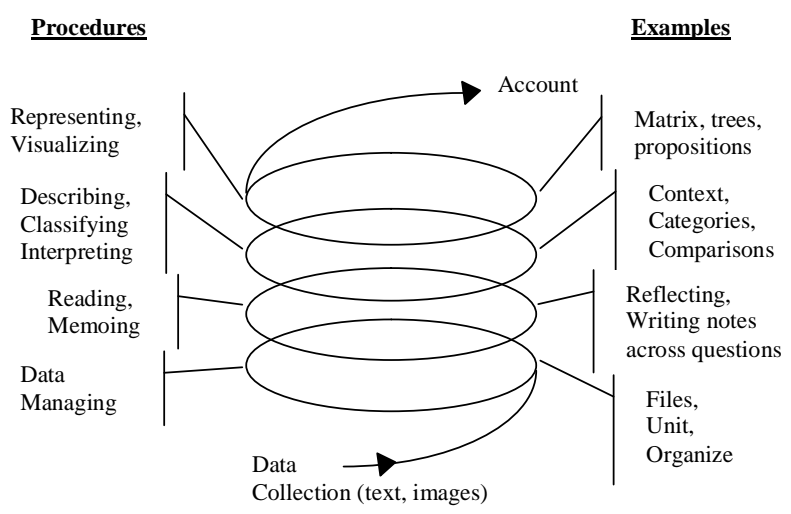

Gambar 2. The Data Analysis Spiral (Creswell, 1998:143) klasifikasi, dan diinterpretasi sehingga menghasilkan konteks, kategori, dan komparasi. Kemudian yang terakhir hasil analisis disajikan dan divisualisasikan dalam gambar pola pendidikan informal dan proses pendidikan informal di organisasi mahasiswa ekstra universiter.

\section{Pengecekan Keabsahan Temuan}

Menurut Lincoln \& Guba (1994) ada beberapa standar atau kriteria guna menjamin keabsahan data kualitatif, antara lain sebagai berikut.

Standar kredibilitas, agar hasil penelitian memiliki kepercayaan yang tinggi sesuai dengan fakta yang ada di lapangan perlu dilakukan: (1) memperpanjang keterlibatan peneliti di lapangan, (2) melakukan observasi terus-menerus dan sunguh-sungguh, sehingga peneliti dapat mendalami fenomena yang ada, (3) melakukan triangulasi, (4) melibatkan atau diskusi dengan teman sejawat, (5) melakukan kajian atau analisis kasus negatif, (6) melacak kesesuaian dan kelengkapan hasil analisis. Agar menghasilkan penelitian yang memiliki kepercayaan yang tinggi maka peneliti: (1) memperpanjang keterlibatan peneliti di lapangan. Penelitian seharusnya sudah selesai bulan maret 2013 akan tetapi karena data yang terkumpul belum lengkap maka peneliti memperpenjang waktu peneltian hingga bulan juni 2013, (2) melakukan observasi secara terus menerus dan sungguh-sungguh sehingga peneliti dapat mendalami pola pendidikan informal dalam organisasi mahasiswa ekstra universiter, (3) melakukan triangulasi. Triangulasi yang dilakukan peneliti adalah triangulasi teknik pengumpulan data, triangulasi sumber data, dan triangulasi teori pendidikan informal, (4) diskusi dengan teman sejawat dilakukan sejak menyusun proposal, seminar proposal, pengumpulan data, hingga penyusunan laporan penelitian tesis.

Standar transferabilitas, konsep ini sejenis dengan konsep validitas eksternal dalam penelitian kualitatif. Cara yang dilakukan peneliti adalah: (1) peneliti membuat laporan penelitian dengan uraian yang rinci, jelas dan sistematis, (2) laporan penelitian dapat dipercaya, sehingga pembaca laporan memperoleh gambaran tentang hasil penelitian dapat diberlakukan (Faisal, 2007). Peneliti membuat laporan penelitian dengan berhati-hati sehingga uraiaannya dibuat rinci, jelas, dan sistematis. Laporan penelitian dilengkapi dengan bukti dan fakta yang valid sehingga dapat dipercaya dan pembaca dapat memperoleh gambaran yang utuh tentang hasil penelitian. 
Standar dependabilitas, adanya pengecekan atau penilaian ketepatan peneliti dalam mengkoseptualisasikan data secara ajeg. Konsitensi peneliti dalam keseluruhan proses penelitian menyebabkan penelitian ini dianggap memiliki dependabilitas tinggi. Peneliti berupaya mengkonseptulisasikan pola pendidikan informal dalam organisasi mahasiswa ekstra universiter secara konsisten. Sehingga dengan konsistensi peneliti dalam kesuluruhan proses penelitian, diharapkan penelitian ini dianggap memiliki keterandalan yang tinggi.

Standar konfirmabilitas, lebih terfokus pada pemeriksaan dan pengecekkan (checking \& audit) kualitas hasil penelitian, apakah benar hasil penelitian didapat dari lapangan. Audit konfirmabilitas umumnya bersamaan dengan audit dependabilitas. Selanjutnya peneliti telah melakukan pemeriksaan dan pengecekan khususnya tahap pengumpulan data, sehingga data yang terkumpul memang benar-benar didapatkan dari lapangan.

\section{HASIL DAN PEMBAHASAN}

\section{Pendidikan Informal di Organisasi Mahasiswa Ekstra Universiter (OMEU)}

Pendidikan informal di OMEU berhasil mereproduksi banyak pemimpin bangsa Indonesia disebabkan karena proses pendidikan informal paling sering berkaitan dengan tema kepemimpinan dan kebangsaan, pendidikan informal di OMEU hakikatnya untuk melahirkan pemimpin bangsa, pendidikan informal berfokus pada karakter, adanya tauladan dalam pendidikan informal, adanya komunitas-komunitas dalam pendidikan informal, adanya lingkungan pendidikan informal, dan pendidikan informal berlangsung terus menerus sampai akhir hayat. Penjelasannya sebagai berikut.

\section{Proses Pendidikan Informal di OMEU dengan Tema Kepemimpinan dan Kebangsaan}

Proses Pendidikan informal di OMEU paling sering berkaitan dengan tema-tema kepemimpinan dan kebangsaan, dapat dilihat dari keseluruhan aktivitas pendidikan informal di OMEU mulai dari percakapan sehari-hari, diskusi-diskusi, buku yang dibaca dan ditulis, tokoh yang ditauladani hingga demonstrasi yang dilakukan paling sering adalah yang berkaitan dengan tema-tema kepemimpinan dan kebangsaan. Sehingga wajar hal tersebut kemudian meningkatkan kapasitas dan wawasan peserta didik informal tentang kepemimpinan dan kebangsaan.
Sesuai dengan pendapat Greenleaf (dalam Maxwell, 1995:145) bahwa wawasan adalah "petunjuk" yang dimiliki pemimpin. Begitu dia kehilangan petunjuk dan peristiwa mulai memberikan tekanan, dia hanyalah pemimpin dalam nama saja. Dia tidak memimpin, dia bereaksi terhadap peristiwa yang muncul seketika dan dia mungkin tidak akan lama menjadi pemimpin. Berlimpah-limpah contoh yang ada tentang kehilangan kepemimpinan yang berasal dari kegagalan melihat sebelumnya apa yang seharusnya dapat dibayangkan secara masuk akal, dan dari kegagalan untuk bertindak berdasarkan apa yang diketahui sementara pemimpin punya kebebasan untuk bertindak.

Proses pendidikan informal di OMEU yang sering menekankan pada hal-hal yang berkaitan dengan tema kepemimpinan dan kebangsaan akan berdampak pada meningkatnya kapasitas kepemimpinan dan wawasan kebangsaan peserta didik informal di OMEU. Sehingga dengan wawasan kebangsaan, peserta didik informal dibekali "petunjuk" untuk menjadi pemimpin bangsa yang tahu tujuan kepemimpinan sesungguhnya dan langkah-langkah apa saja yang ditempuh untuk mewujudkan tujuan kepemimpinan tersebut.

\section{Pendidikan Informal di OMEU Hakikatnya Mereproduksi Pemimpin Bangsa}

Pendidikan informal di OMEU hakikatnya untuk mereproduksi pemimpin-pemimpin bangsa, hal ini didasarkan pada fakta bahwa OMEU merupakan organisasi kader yang nampak dari konten dari pendidikan informal di OMEU hampir semuanya berkutat tentang wawasan, nilai-nilai, dan kecakapan yang dimiliki seorang pemimpin bangsa. Konten pendidikan informal di OMEU dibagi dalam 3 aspek. Aspek 1 pengetahuan dan wawasan meliputi wawasan kebangsaan, wawasan keagamaan, intelektualitas, pendidikan politik, dan membongkar kesadaran. Aspek 2 nilai-nilai, keyakinan dan sikap yang dikembangkan di OMEU yaitu tentang ideologisasi, spiritualitas, integritas, keberanian, pantang menyerah, kebijaksanaan, tanggung jawab, menjadi diri sendiri, kedisiplinan, kemandirian, kekeluargaan, gotong royong, kerelaan untuk berbagi, kebanggaan organisasi, manfaat bagi sesama manusia, dan keberpihakan pada rakyat. Aspek 3 kecakapan yang diperoleh di OMEU diantaranya meliputi bagaimana menjadi pemimpin, komunikasi, mempengaruhi orang, pengambilan keputusan, menejemen organisasi, menejemen konflik, menejemen resiko, analisis masalah masyarakat, pendamping masyarakat, bertindak nyata, bekerja sama dengan semua pihak, dan membangun jaringan. 
Konsep reproduksi pemimpin Maxwell (1997: 324) menyebutkan bahwa seorang pemimpin yang menghasilkan pemimpin lainnya melipatgandakan pengaruhnya, demikian pula dia dan anak buahnya mempunyai masa depan. Organisasinya terus berkembang dan tumbuh bahkan seandainya dia secara pribadi tidak dapat meneruskan peranan kepemimpinannya.

Hakikatnya pendidikan informal diarahkan mencapai tujuan OMEU sebagai organisasi kader, yaitu organisasi yang menghasilkan pemimpin-pemimpin di tiap generasinya dan tiap generasi bertanggung jawab untuk menghasilkan pemimpin-pemimpin berikutnya sehingga akan terus melipatgandakan pengaruhnya tiap generasinya. Hal ini sudah menjadi kultur di OMEU dan terus berkembang untuk mereproduksi pemimpin-pemimpin bangsa. Dengan reproduksi secara berkelanjutan diharapkan mampu menghasilkan pemimpin-pemimpin bangsa yang dapat mengimplementasikan wawasan, nilai-nilai, dan kecakapan dalam kehidupan sehari-hari yang telah ditanamkan di OMEU.

\section{Pendidikan informal di OMEU berfokus pada karakter}

Pendidikan informal di OMEU berfokus pada karakter, sehingga hal ini sangat menopang dalam mewujudkan pemimpin bangsa yang berkarakter. Pendidikan informal di OMEU mengembangkan pemimpin bangsa yang karakter memegang teguh ideologi, spiritualitas, integritas, keberanian, pantang menyerah, kebijaksanaan, tanggung jawab, kedisiplinan, kemandirian, kekeluargaan, kerelaan untuk berbagi, dan keberpihakan pada rakyat.

Hal ini sesuai dengan pendapat Gibson, Ivancevich, \& Donnelly (2002: 11) bahwa semua karakteristik utama dari kepemimpinan, kecuali karisma, dapat dipelajari dan/atau dimiliki oleh orang lain. Beberapa hasil penelitian menyiratkan bahwa sifat kepribadian seperti kesiagaan, keaslian, integritas pribadi, dan percaya diri diasosiasikan dengan kepemimpinan yang efektif.

Pendidikan informal di OMEU sangat menopang dalam mewujudkan pemimpin bangsa yang berkarakter memegang teguh ideologi, spiritualitas, integritas, keberanian, pantang menyerah, kebijaksanaan, tanggung jawab, kedisiplinan, kemandirian, kekeluargaan, kerelaan untuk berbagi, dan keberpihakan pada rakyat. Karakter-karakter tersebut diajarkan dan dipelajari dalam pendidikan informal di OMEU untuk mewujudkan kepemimpinan bangsa yang efektif.

\section{Tauladan dalam Pendidikan Informal di OMEU}

Tauladan dalam pendidikan informal di OMEU memiliki peranan sangat penting untuk mereproduksi pemimpin bangsa, karena dalam mereproduksi pemimpin bangsa tidak cukup hanya memahami wawasan, nilai-nilai, dan kecakapan yang harus dimiliki oleh seorang pemimpin bangsa. Akan tetapi untuk mereproduksi pemimpin bangsa diperlukan sosok yang menjadi tauladan, sehingga dapat menjadi pemicu untuk semakin bertekad dan mengimplementasikannya dalam kehidupan sehari-hari terkait pemahamannya tentang wawasan, nilai-nilai, dan kecakapan yang harus dimiliki oleh seorang pemimpin bangsa.

Hal tersebut sesuai dengan pendapat Maxwell (1997:32) bahwa bagian dari menciptakan lingkungan yang menarik adalah mengambil tauladan kepemimpinan. Orang meniru apa yang mereka lihat sebagai tauladan. Apa yang dilakukan pemimpin akan dilakukan pula oleh calon pemimpin di sekelilingnya. Apa yang dihargainya, akan dihargai pula oleh anak buahnya. Tujuan pemimpin menjadi tujuan mereka.

Pendidikan informal di OMEU menekankan pentingnya tauladan yang mampu menginternalisasi wawasan, nilai-nilai, dan kecakapan seorang pemimpin bangsa dalam tutur, sikap, dan perilakunya seharihari. Sehingga memudahkan peserta didik informal dalam memahami dan melakukan apa saja yang dianggap sebagai tauladan untuk menjadi pemimpin bangsa.

\section{Komunitas-Komunitas dalam Pendidikan Informal di OMEU}

Adanya komunitas-komunitas dalam pendidikan informal di OMEU peranannya sangat vital untuk mereproduksi dan mendidik pemimpin bangsa, karena komunitas-komunitas ini berfungsi selayaknya keluarga yang melahirkan dan kemudian merawat pemimpin bangsa dengan tulus ikhlas.

Hal tersebut sesuai dengan pernyataan Gibson, Ivancevich, dan Donnelly (2002:404) bahwa kelompok informal terbentuk karena upaya individu atau inisiatif karyawan. Kelompok ini berkembang karena adanya minat dan untuk persahabatan. Meskipun bukan sebagai bagian formal organisasi, kelompok ini bisa berpengaruh terhadap kinerja organisasi dan individual.

\section{Lingkungan Pendidikan Informal di OMEU}

Lingkungan pendidikan informal di OMEU sangat menunjang reproduksi pemimpin bangsa, karena 
memberikan iklim yang dapat membuat kader memacu dirinya semaksimal mungkin. Sehingga kalau memang kader tersebut ingin menjadi orang yang hebat pasti diberi ruang. Karena tidak ada pembatasan atas kreativitas individu, sehingga kader bisa maju dan tanpa sadar untuk berkompetisi dengan yang lainnya dalam kebaikan. Jadi denyutnya OMEU adalah iklim yang membawa kadernya mau tidak mau, sadar atau tidak sadar, saat sudah masuk OMEU kader akan dilatih dan dicetak untuk menjadi seorang pemimpin bangsa.

Hal tersebut sesuai dengan penjelasan Maxwell (1997:31) bahwa untuk melihat hubungan antara lingkungan dan pertumbuhan alam. Sebuah penelitian pernah dilakukan oleh orang yang menyelam untuk menangkap ikan eksotik yang akan dipelihara dalam aquarium dan yang paling populer adalah hiu. Alasannya karena hiu menyesuaikan dirinya dengan lingkungannya. Seekor hiu kecil akan tetap dalam ukuran yang sesuai dengan aquarium tempatnya hidup. Ikan hiu bisa sepanjang 6 inci dan dewasa penuh. Tetapi lepaskanlah ikan ini di samudera dan dia akan tumbuh sampai ukuran yang normal.

Lingkungan di OMEU baik internal dan eksternal yang begitu dahsyat sangat menunjang mereproduksi pemimpin bangsa karena lingkungan memberikan iklim yang dapat membuat kader memacu dirinya semaksimal mungkin. Tidak adanya pembatasan atas kreativitas individu menyebabkan peserta didik informal dapat maju dan tanpa sadar berkompetisi dengan yang lainnya dalam kebaikan.

\section{Pendidikan Informal di OMEU Terus Menerus Sampai Akhir Hayat}

Pendidikan informal di OMEU berlangsung terus-menerus, sehingga memungkinkan tidak terbatasnya interaksi yang terjadi antara pendidik informal, peserta didik informal, komunitas-komunitas, dan lingkungannya. Proses interaksi yang intensif kemudian dapat mereproduksi sosok-sosok tauladan baru dengan komunitas-komunitas baru yang mampu mereproduksi pemimpin-pemimpin bangsa berikutnya. Walaupun sudah berusia senja, masih dapat memberikan petuah-petuah dan menjadi tauladan bagi yang lebih muda untuk tetap bersemangat menjaga dan memperjuangkan nilai-nilai kebaikan.

Hal tersebut sesuai dengan konsep reproduksi pemimpin oleh Maxwell (1997:324-325) bahwa sebagai seorang pemimpin anda telah memelihara, memperlengkapi, dan mengembangkan mereka. Anda telah membina satu tim besar dan belajar melatih mereka. Pada saat ini, mungkin anda berpikir bahwa peker- jaan sudah selesai. Tidak demikian, ada satu lagi unsur yang mutlak penting, dan itu adalah ujian sukses yang sesungguhnya bagi seorang pemimpin yang mengembangkan pemimpin lainnya. Pemimpin yang anda kembangkan harus meneruskan tradisi mengembangkan dan menghasilkan generasi pemimpin yang ketiga. Kalau tidak, proses pembinaan berhenti sampai batas mereka. Sukses yang sesungguhnya hanya datang setelah setiap generasi terus mengembangkan generasi berikutnya, mengajarkan kepada mereka nilai dan metode mengembangkan kelompok pemimpin berikutnya.

Proses pendidikan informal di OMEU berlangsung terus menerus sampai akhir hayat, sehingga memungkinkan tidak terbatas dan berkembangnya interaksi yang terjadi antara pendidik informal, peserta didik informal, komunitas-komunitas, dan lingkungannya untuk mengembangkan pemimpin-pemimpin bangsa berikutnya secara berkelanjutan. Pemimpin bangsa yang sudah berhasil, meneruskan tradisi mendidik dan menghasilkan generasi pemimpin baru dan generasi pemimpin baru tersebut juga mendidik dan menghasilkan generasi pemimpin baru lagi, dan terus bergulir. Kalau tidak, proses pendidikan berhenti sampai batas mereka. Sukses yang sesungguhnya hanya datang setelah setiap generasi terus mendidik generasi berikutnya.

\section{Pola Pendidikan Informal di OMEU}

Pola pendidikan informal di OMEU meliputi individu-individu, komunitas, lingkungan, dan Interaksi pendidikan informal. Pola pendidikan informal di OMEU Dapat digambarkan seperti pada Gambar 3.

Gambar 3 dikembangkan dari temuan lapangan dan merujuk batasan Coombs, Prosser \& Ahmed (1973:10); Axinn (1974:8); dan Jeffs \& Smith (2005: 11) sehingga peneliti menyimpulkan bahwa keberadaan pendidik informal dalam interaksi pendidikan informal memang ada, akan tetapi tidak harus selalu ada. Sehingga dapat disimpulkan bahwa pendidikan informal merupakan proses sepanjang hayat. Seseorang memperoleh dan menghimpun pengetahuan, keterampilan, sikap dan pandangan dari pengalaman dan terpaan lingkungan. Pengalaman diperoleh terutama melalui proses pendidikan diri (self-education), akan tetapi memungkinkan juga pengalaman tersebut diperoleh setelah melakukan interaksi dengan individu lain sebagai pendidik informal.

Ada hal yang perlu di pahami dulu terkait gambar 3 melalui analogi berikut, yaitu misalkan individu A 


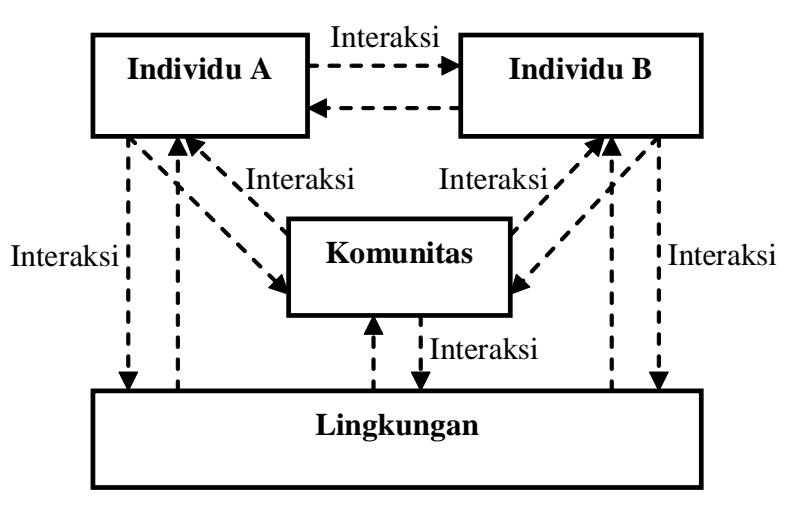

Gambar 3. Pola Pendidikan Informal di OMEU

pada awalnya berperan menjadi pendidik informal akan tetapi bisa saja kemudian individu A berubah peran menjadi peserta didik informal. Sebaliknya misalkan individu B yang pada awalnya berperan menjadi peserta didik informal akan tetapi bisa saja kemudian individu B tersebut kemudian berubah peran menjadi pendidik informal. Pada hakikatnya setiap orang adalah sumber belajar, sehingga pada saat tertentu dan tentang beberapa hal seseorang dapat berperan sebagai pendidik informal, tetapi pada saat lain seseorang dapat menjadi peserta didik informal.

Gambar 3 dapat dijelaskan sebagai berikut, individu Amelakukan 2 interaksi pendidikan informal yaitu (1) pada satu sisi dengan sengaja berperan menjadi pendidik informal melakukan interaksi untuk mempengaruhi individu $B$, komunitas, dan lingkungan, tetapi (2) pada sisi lain individu Ajuga dapat berperan menjadi peserta didik informal yang dapat belajar tentang sesuatu hal setelah melakukan interaksi dengan individu B, komunitas, dan lingkungan.

Individu B juga melakukan 2 interaksi pendidikan informal yaitu (1) pada satu sisi dengan sengaja berperan menjadi pendidik informal melakukan interaksi untuk mempengaruhi individu $\mathrm{A}$, komunitas, dan lingkungan, tetapi (2) pada sisi lain individu B juga dapat berperan menjadi peserta didik informal yang dapat belajar tentang sesuatu hal setelah melakukan interaksi dengan individu A, komunitas, dan lingkungan.

Komunitas di OMEU setelah melakukan interaksi pendidikan informal, pada satu sisi bisa mempengaruhi individu A, individu B, dan lingkungan. Akan tetapi pada sisi lain komunitas juga dipengaruhi oleh individu A, individu B, dan lingkungan. Dalam hal ini komunitas di OMEU jumlahnya banyak.

Lingkungan di OMEU setelah mengalami interaksi pendidikan informal, pada satu sisi dapat mempengaruhi individu A, individu B, dan komunitas, tetapi pada sisi lain lingkungan juga dipengaruhi oleh individu A, individu B, dan komunitas. Komponen-komponen pendidikan informal di OMEU dijelaskan sebagai berikut.

\section{Individu}

Setiap individu di Organisasi Mahasiswa Ekstra Universiter bisa berperan menjadi pendidik informal ataupun menjadi peserta didik informal. Berikut penjelasannya.

Sebagai Pendidik Informal di OMEU. Ada 5 hal penting yang harus dimiliki individu sebagai pendidik informal di OMEU yaitu disebabkan karena dorongan hati, pendidik informal sebagai tauladan, pendidik informal mempunyai metode yang khas, pendidik informal selalu berprasangka baik dan imbalan pendidik informal adalah kebahagiaan.

Sebagai Peserta Didik Informal di OMEU. Ada 4 hal yang harus dilakukan oleh individu sebagai peserta didik informal di OMEU yaitu belajar mandiri, belajar pada banyak orang, mendatangi tokoh, dan mendatangkan tokoh.

\section{Komunitas di OMEU}

Perlu dipahami bahwa komunitas merupakan bagian penting dalam proses pendidikan informal di OMEU. Komunitas muncul secara alamiah dan sukarela setelah ada berbagai proses interaksi secara bersama-sama sehingga kemudian terciptanya rasa kekeluargaan antar individu tersebut sehingga sebagian pendidikan bisa terorganisir secara mandiri. Pola komunitas di OMEU biasanya berjarak 5 sampai 10 tahun dan tiap angkatannya ada tokoh organizernya, sehingga benar-benar tercipta teamwork. Komunitas yang dimaksud berupa komunitas di kepengurusan OMEU, komunitas pengurus alumni OMEU, komunitas alumni OMEU yang se-profesi, dan masih banyak lagi komunitas kultural baik yang masih aktif maupun yang sudah menjadi alumni OMEU.

Komunitas bertujuan untuk kebaikan dan membangun peradaban bangsa. Sehingga alumni OMEU yang mempunyai posisi dan kewenangan, entah itu walikota, DPR, LSM dan elemen-elemen yang lain bersama-sama masyarakat saling membantu memperbaiki situasi bangsa.

\section{Lingkungan di OMEU}

Lingkungan sebagai bagian yang juga sangat mempengaruhi dalam proses pendidikan informal di OMEU. Lingkungan di OMEU meliputi dua hal yaitu lingkungan internal dan lingkungan eksternal. Lingkungan internal meliputi lingkungan yang ada di kepe- 
ngurusan maupun lingkungan yang ada di alumni. Lingkungan eksternal merupakan lingkungan-lingkungan yang ada di luar lingkungan, diantaranya adalah lingkungan organisasi-organisasi mahasiswa ekstra universiter diluar OMEU beserta alumninya, lingkungan suatu perguruan tinggi, lingkungan suatu daerah, hingga situasi dan kondisi bangsa Indonesia yang meliputi segala aspek kehidupan.

Lingkungan internal dan lingkungan eksternal di OMEU masing-masing meliputi dua jenis lingkungan, yaitu lingkungan sosial dan lingkungan fisik. Lingkungan Sosial fokusnya adalah pada hubungan antara orang-orang bukan kondisi fisik atau material. Individu berpartisipasi dalam beberapa aktivitas - baik itu berbicara, menonton video atau membuat beberapa hal. Proses tersebut memiliki makna bagi masingmasing yang terlibat. Lingkungan fisik meliputi bentuk ruangan, cara kursi ditata, dan pencahayaan yang mempengaruhi cara merasa dan berpikir tentang kegiatan.

\section{Interaksi dalam Pendidikan Informal di OMEU}

Interaksi dalam pendidikan informal di OMEU meliputi prinsip, strategi, dan konten pendidikan informal, berikut ini paparannya.

Prinsip Pendidikan Informal di OMEU. Prinsip pendidikan informal di OMEU ada 9 hal yaitu proses sa-ling belajar; dilakukan dalam interaksi sehari-hari; terjadi dimanapun dan kapanpun; terjadi dalam segala situasi dan kondisi; belajar dari apapun dan siapapun; bisa belajar tentang apapun; bersifat alamiah, tidak terasa dan bertahap; berfokus pada karakter; dan berlangsung sampai akhir hayat.

Strategi Pendidikan Informal di OMEU. Strategi pendidikan informal di OMEU dapat melalui percakapan; membaca dan menulis; diskusi; menjadi tauladan; mentoring; memberi tanggung jawab; mengajak bertemu tokoh; wayangan, turun lapangan; demonstrasi; dan distribusi kader.

Konten Pendidikan Informal. Konten pendidikan informal meliputi 3 hal yaitu pengetahuan dan wawasan; nilai-nilai, keyakinan dan sikap; dan kecakapan. Berikut uraiannya: (1) pengetahuan dan wawasan penting dimiliki oleh setiap pemimin bangsa sebab menjadi modal tentang apa yang akan dicapai. Di samping itu pengetahuan dan wawasan menjadi energi dibalik setiap upaya dan daya yang memberikan dorongan bagi seorang pemimpin. Dengan pengetahuan dan wawasan, pemimpin berada dalam misi dan semangat yang menular di tengah-tengah orang banyak sampai yang lainnya mulai bangkit di sisi pemim- pin. Kesatuan sangat penting agar mimpi dapat terealisasi. Jam kerja yang panjang diberikan dengan senang hati untuk mencapai tujuan. Hak-hak individu dikesampingkan karena keseluruhan jauh lebih penting dari pada bagian. Waktu berlalu dengan cepat, moral membumbung tinggi, kisah heroik diceritakan, dan komitmen merupakan kata sandi. Pengetahuan dan wawasan di OMEU meliputi wawasan kebangsaan, wawasan keagamaan, intelektualitas, pendidikan politik, dan membongkar kesadaran.

(2) Pentingnya nilai-nilai, keyakinan dan sikap di OMEU untuk diinternalisasi dalam diri sehingga akan menjadi (sadar atau bawah sadar) sebuah standar atau kriteria untuk menuntun tindakan seorang pemimpin bangsa yang berkarakter. Nilai-nilai, keyakinan dan sikap yang dikembangkan di OMEU diantaranya adalah ideologisasi, spiritualitas, integritas, keberanian, pantang menyerah, kebijaksanaan, tanggung jawab, kerja keras, menjadi diri sendiri, kedisiplinan, kemandirian, kekeluargaan, gotong royong, kerelaan untuk berbagi, kebanggaan organisasi, musyawarah mufakat, manfaat bagi sesama manusia, keberpihakan pada rakyat, dan kepedulian akan alam.

(3) Kecakapan kepemimpinan ditanamkan dalam penugasan operasional OMEU sehari-hari atau dilakukan sejalan dengan penugasan. Kecakapan kepemimpinan menjadi satu dengan aktivitas seharihari peserta didik informal. Penekanannya adalah belajar mandiri dan belajar dari pengalaman. Kecakapan yang diperoleh di OMEU meliputi menjadi pemimpin, komunikasi, mempengaruhi orang, pengambilan keputusan, menejemen organisasi, menejemen konflik, menejemen resiko, analisis masalah masyarakat, pendamping masyarakat, bertindak nyata, bekerja sama dengan semua pihak, dan membangun jaringan

\section{SIMPULANDAN SARAN}

\section{Simpulan}

Hasil penelitian adalah: (1) pendidikan informal di OMEU berhasil mereproduksi banyak pemimpin bangsa Indonesia, dikarenakan: proses pendidikan informal paling sering berkatian dengan tema kepemimpinan dan kebangsaan, pendidikan informal di OMEU hakikatnya untuk melahirkan pemimpin bangsa, pendidikan informal berfokus pada karakter, adanya tauladan dalam pendidikan informal, adanya komunitas-komunitas dalam pendidikan informal, adanya lingkungan pendidikan informal, dan pendidikan informal berlangsung terus menerus sampai akhir 
hayat; (2) Pola pendidikan informal di OMEU merupakan interaksi yang terjadi secara terus menerus antara individu-individu, komunitas, dan lingkungan. dalam hal ini setiap individu bisa berperan menjadi pendidik atau peserta didik informal yang bisa mempengaruhi atau dipengaruhi individu lain, komunitas, dan lingkungannya.

\section{Saran}

Saran-saran dalam penelitian ini ditujukan (1) bagi Organisasi Mahasiswa Ekstra Universiter agar terus mengembangkan pendidikan informal dalam mereproduksi pemimpin bangsa. Organisasi mahasiswa ekstra universiter diharapkan mampu merangkul dan bersikap inklusif kepada semua pihak, sehingga mampu mengembangkan iklim pendidikan informal tidak hanya di internal OMEU akan tetapi juga mampu berperan aktif dalam membenahi situasi dan kondisi masyarakat, bangsa dan Negara Indonesia untuk lebih baik; (2) bagi Direktorat Jenderal Pendidikan Tinggi Kementerian Pendidikan dan Kebudayaan agar mencabut kebijakan yang menghambat berkembangnya pendidikan informal dalam organisasi mahasiswa ekstra universiter dan mengganti dengan kebijakan yang berpihak pada pengembangan proses pendidikan informal dalam organisasi mahasiswa ekstra universiter yang telah terbukti berhasil mereproduksi banyak pemimpin bangsa; (3) bagi Perguruan Tinggi agar dapat bermitra dengan organisasi mahasiswa ekstra universiter dalam mengembangkan pendidikan informal untuk mereproduksi pemimpin bangsa. Perguruan Tinggi dapat berperan aktif menjawab permasalahan krisis kepemimpinan bangsa Indonesia saat ini; (4) bagi Jurusan Pendidikan Luar Sekolah agar memperbanyak penelitian tentang pendidikan informal sehingga dapat menambah bukti empirik dan semakin kokohnya teori pendidikan informal. Jurusan Pendidikan Luar Sekolah diharapkan mampu menjadi pioneer dalam menumbuhkembangkan pendidikan informal melalui aktivitas-aktivitas berbasis komunitas, organisasi dan masyarakat.

\section{DAFTARRUJUKAN}

Axinn, G.H. 1974. Toward a Srategy of International Interaction in Nonformal Education. East Lansing: Michigan State University.

Coombs, P. H. \& Ahmed, M. 1974. Attacking Rural Poverty. Baltimore: The John Hopkins University Press.

Cresswell, J.W. 1998. Qualitative Inquiry and Research Design: Choosing Among Five Traditions. California: SAGE Publications, Inc.

Faisal, S. 2007. Penelitian Kualitatif: Dasar dan Aplikasi. Malang: YA3

Fatchan, A. 2011. Metode Penelitian Kualitatif: Beserta Contoh Proposal Skripsi, Tesis, dan Disertasi. Surabaya: Jenggala Pustaka Utama

Gibson, J.L., Ivancevich, J.M., \& Donnelly, J.H. 2002. Organisasi: Perilaku, Struktur, \& Proses. Jilid 1. Tangerang: Binarupa Aksara.

Jeffs, T. and Smith, M. K. 2005. Informal Education: conversation, democracy and learning $3 \mathrm{e}$. Nottingham: Educational Heretics Press.

Lincoln, I.S \& Guba, E.G. 1994. Naturalictic Inquiry. London-New Delhi: Sage Publication Inc.

Maxwell, J.C. 1995. Mengembangkan Kepemimpinan di Dalam Diri Anda. Jakarta: Binarupa Aksara.

Maxwell, J.C. 1997. Mengembangkan Kepemimpinan di Sekeliling Anda: Bagaimana Cara Membantu Orang Lain Mencapai Potensi Penuh Mereka. Jakarta: Professional Books.

Miles, M.B. \& Huberman, A.M. 1994. Qualitative Data Analysis: A Sourcebook of New Methods. Beverly Hills, CA: Sage.

Moedzakir, M.D. 2010. Desain dan Model Penelitian Kualitatif: Biografi, Fenomenologi, Teori Grounded, Etnografi, dan Sudi Kasus. Malang: Fakultas Ilmu Pendidikan Universitas Negeri Malang.

Universitas Negeri Malang. 2010. Pedoman Penulisan Karya Ilmiah: Skripsi, Tesis, Disertasi, Artikel, Makalah, Tugas Akhir, Laporan Penelitian. Edisi kelima. Malang: Universitas Negeri Malang

Spradley, J. 1979. The Ethnographic interview. New York: Holt, Rinehart Winston.

Undang-Undang Dasar 1945 Hasil Amandemen IV.

Yin, R.K. 2003. Case Study Research: Design and Methods- $3^{\text {rd }}$ Ed (Applied Social Research Methods Series: v.5). California: SAGE Publication, Inc. 